\title{
PELATIHAN PEMBUATAN ALAT DETEKSI SEDERHANA BORAKS DAN FORMALIN
}

\author{
Dadan Supardan \\ Universitas Islam Negeri Mataram, Mataram, Indonesia \\ dadan.supardan@uinmataram.ac.id
}

\begin{abstract}
Abstrak: Salah satu masalah kesehatan di Indonesia adalah rendahnya kesadaran para pedagang makanan kecil tentang keamanan pangan. Penggunaan bahan pengawet berbahaya yang tidak diperuntukan untuk makanan seperti boraks dan formalin masih banyak digunakan. Masyarakat memiliki peran penting untuk turut mengawasi peredaran makanan yang diduga mengandung pengawet berupa boraks dan formalin. Tujuan pengabdian masyarakat ini adalah mengedukasi masyarakat mengenai bahan kimia berbahaya yang digunakan untuk pengawet makanan dan melatih masyarakat untuk membuat alat deteksi sederhana boraks dan formalin menggunakan bahan yang murah, mudah dengan hasil yang cukup akurat secara kualitatif. Metode yang digunakan yaitu metode eksperimen dengan pendekatan laboratorium yang akan dilakukan dengan serangkaian percobaan. Bahan yang digunakan antara lain kunyit, tusuk gigi, kalium permanganat, dan kertas saring. Sampel makanan yang dianalisis pada kegiatan ini adalah mie kuning basah dan bakso yang diambil secara acak di pedagang pasar pagesangan di Kota Mataram. Hasil dari pengabdian ini yaitu masyarakat menjadi teredukasi mengenai bahan kimia berbahaya yang masih digunakan masyarakat sebagai pengawet dan masyarakat mampu membuat alat deteksi boraks dan formalin sederhana pada makanan.
\end{abstract}

Kata Kunci: boraks, formalin, makanan pasar, pengawet makanan

\begin{abstract}
One of the health problems in Indonesia is the low awareness of food sellers about food safety. Hazardous preservatives that are not intended for food, such as borax and formalin, are still widely used. The community has a vital role in supervising the circulation of food suspected of containing the preservatives. This community service aims to educate people about hazardous chemicals used for food preservatives and train them to make a simple detection tool for borax and formalin using cheap materials with reasonably accurate results. The method used is an experimental method with a laboratory approach carried out with a series of experiments. The materials used include turmeric, toothpicks, potassium permanganate, and filter paper. The food samples analyzed in this activity were wet yellow noodles and meatballs taken randomly at Pagesangan market in Mataram City. This program's result is that the people get educated about dangerous chemicals still used by the sellers as preservatives and can make the simple borax and formalin detection tool.
\end{abstract}

Keywords: borax, formalin, street food, food aditives

\section{Pendahuluan}

Keamanan pangan merupakan salah satu isu kesehatan utama di Indonesia yang perlu ditangani bersama baik oleh pemerintah, produsen maupun konsumen (masyarakat). Produsen pangan bertanggung jawab untuk mengendalikan kualitas dan keamanan pangan yang diproduksi, konsumen bertanggung jawab mengawasi keamanan pangan yang dijual di masyarakat, sedangkan pemerintah bertanggung jawab untuk menegur dan mengawasi keamanan pangan yang beredar di masyarakat (Ziska L, 2016; Atiqullah et al., 2019; FemiOloye et al., 2020). Salah satu masalah keamanan pangan di Indonesia adalah pengetahuan, keterampilan dan tanggung jawab produsen makanan atau minuman yang masih rendah mengenai mutu dan keamanan pangan, terutama para industri kecil atau industri rumah tangga (Oktaviani I, 2017; Asif Ahmed, Al-Khalifa, Al-Nouri, \& El-din, 2020; Boutillier, Fourmentin, \& 
Laperche, 2020). Selain itu tingkat pemahaman dan Pendidikan masyarakat (selaku produsen sekaligus konsumen) juga sangat berpengaruh terhadap tingkat Kesehatan pada masyarakat tersebut bahkan mencapai 55\% (Pradono \& Sulistyowati, 2014).

Secara umum upaya pengolahan makanan bertujuan untuk menghasilkan produk makanan yang disukai serta berkualitas. Makanan yang tersaji harus tersedia dalam bentuk dan aroma yang lebih menarik, rasa enak, warna dan konsistensinya baik serta awet. Untuk mendapatkan makanan seperti yang diinginkan, maka dalam proses pembuatannya dilakukan penambahan bahan tambahan makanan atau disebut food additive. Fungsi pemberian food additive adalah untuk mencegah atau memperlambat kerusakan pangan, memperpanjang masa simpan pangan segar atau mencegah pembusukan akibat serangga pada bahan pangan yang disimpan dalam jumlah besar (Cahyadi, W. 2008; Lemoine et al., 2020).

Dalam impelementasinya, masih saja ditemukan kelompok masyarakat yang menggunakan bahan kimia berbahaya seperti boraks dan formalin dalam proses produksi makanan. Boraks merupakan bahan kimia yang berbentuk kristal putih yang lunak, akan menghasilkan produk dengan tekstur kenyal dan kesat jika ditambahkan kedalam makanan. Boraks adalah salah satu elemen yang pada umumnya digunakan pada bahan solder, bahan pembersih, pengawet kayu, antiseptik, dan pembasmi serangga (Cahyadi, W. 2008). Sedangkan Formalin (formaldehid) adalah cairan jernih yang tidak berwarna dengan bau yang menusuk, dan digunakan sebagai bahan untuk obat luar untuk mengobati kutil. Boraks dan formalin disalah gunakan sebagai pengawet makanan dengan tujuan dapat memperpanjang daya awet, mengenyalkan makanan, memperbaiki tekstur, dan warna. Makanan dengan jumlah kontaminasi boraks berlebihan dapat menyebabkan keracunan bahkan kematian (Swi See et al., 2010).

Menurut Peraturan Menteri Kesehatan Nomor 033 tahun 2012 tentang bahan tambahan pangan, Boraks termasuk bahan kimia berbahaya dan beracun dan merupakan salah satu bahan yang dilarang digunakan dalam pangan sebagai bahan tambahan makanan. Bahaya yang ditimbulkan bukan hanya dalam jangka pendek tetapi juga jangka Panjang (Kementerian Kesehatan Republik Indonesia, 2012). Meskipun masyarakat (produsen) pangan sudah mengetahui bahwa boraks dan formalin ini berbahaya dan dilarang oleh pemerintah, namun masih saja ditemukan kasus yang menggunakan bahan berbahaya ini (formalin dan boraks) karena harganya yang murah. Rendahnya pengetahuan dan kesadaran konsumen (masyarakat) mengenai bahaya boraks dan formalin bagi kesehatan menyebabkan tidak adanya upaya preventif dari masyarakat untuk memilih makanan yang ada di pasaran. Selain itu, banyaknya nama lain dari boraks (pijer, bleng, obat gendar, cetitet, obat puli, Sode, obat lontong) membuat masyarakat tidak sadar bahwa bahan yang mereka gunakan adalah boraks.

Dari hasil pengujian sampel pengujian laboratorium Badan Pengawasan Obat dan Makanan (BPOM) yang dilakukan selama tahun 2011 mencakup wilayah Bandar Lampung, Jakarta, Bandung, Semarang, Yogyakarta, Surabaya, Mataram, dan Makassar telah dilakukan pengambilan sampel dan pengujian laboratorium sejumlah 20.511 sampel pangan. Hasil pengujian menunjukkan bahwa $2.902(14,15 \%)$ sampel tidak memenuhi persyaratan keamanan dan mutu antara lain: 151 sampel mengandung Formalin; 138 sampel mengandung Boraks; 3 
sampel mengandung Methanyl Yellow, 1 sampel mengandung Auramin; 197 sampel mengandung Rhodamin B; dan 1.002 sampel mengandung cemaran mikroba melebihi batas. Selain itu, masih terdapat 253 sampel mengandung pengawet Benzoat, 416 sampel mengandung pemanis buatan (siklamat/sakarin/aspartam/asesulfam) yang penggunaannya melebihi batas yang diizinkan, dan atau tidak memenuhi syarat label karena tidak mencantumkan jenis pemanis yang digunakan dan jumlah Acceptable Daily Intake (ADI) (Badan POM, 2011). Selain itu, pengujian terhadap 277 sampel makanan yang berasal dari industri rumah tangga di Kota Mataram, ditemukan 32,49\% sampel atau sebanyak 90 sampel makanan tidak memenuhi syarat, dan diantaranya ditemukan sampel-sampel positif boraks (sampel mie kuning basah dan kerupuk) (BPOM Mataram, 2017).

Untuk mengetahui ada atau tidaknya kandungan boraks pada makanan, maka harus dilakukan uji laboratorium. Di sisi lain masyarakat juga perlu dibekali pengetahuan untuk mendeteksi kandungan boraks pada makanan menggunakan teknik yang sederhana agar mudah diterapkan. Kegiatan pengabdian masyarakat ini bertujuan memberikan pelatihan pembuatan alat deteksi sederhana boraks dan formalin pada masyarakat. Sasaran dari kegiatan ini adalah Para Guru dan Murid Madrasah Aliyah Nurul Mujtahidin NW Lempuan Desa Durian, Kecamatan Janapria Lombok Tengah.

\section{Metode}

Pelaksanaan pengabdian atau pendampingan dilakukan pada hari Sabtu tanggal 21 Juli 2018 mulai dari pukul 08.00 sampai dengan pukul 16.00 WITA dengan melibatkan Narasumber yaitu Dosen dengan bidang keilmuan Kesehatan serta melibatkan mahasiswa sebagai pendamping. Pelaksanaan pengabdian masyarakat ini menggunakan dua cara yaitu (1) ceramah-diskusi mengenai bahan tambahan pangan dan (2) latihan praktek membuat alat pendeteksi boraks. Adapun tahapan pengabdian adalah sebagai berikut:

1. Kegiatan Penyuluhan Pada Guru dan Murid MA Nurul Mujtahidin NW Lempuan

a. Penyuluhan

Kegiatan pengabdian ini dimulai dengan memberikan penyuluhan berupa ceramah dan diskusi untuk memberikan wawasan masyarakat mengenai pentingnya mengetahui bahaya penggunaan bahan tambahan pangan pada makanan olahan, khususnya boraks dan formalin. Penyuluhan ini dilakukan dengan cara penyampaian materi dalam bentuk presentasi dan diskusi, serta disampaikan oleh narasumber yang berpengalaman di bidang kesehatan khususnya mengenai keamanan pangan dan pengujian pangan.

b. Pelatihan pembuatan alat deteksi boraks dan formalin

Pelatihan dilakukan dengan narasumber terlebih dahulu mendemontrasikan pembuatan alat pendeteksi boraks dan formalin (Gambar 1, 2 dan 3). Kemudian peserta bergantian maju ke depan melakukan pengujian borkas dan formalin dengan melihat bentuk, warna dan bau serta melakukan pengujian makanan secara langsung terhadap makanan yang mengandung boraks. Pembuatan dan pengujian alat deteksi sederhana tersebut juga dilakukan oleh perwakilan peserta pengabdian (Guru, Siswa dan perwakilan 
masyarakat). Bahan dan alat yang digunakan pada pelatihan ini yaitu kertas saring, tusuk gigi, boraks, formalin, kunyit, air bersih, PK (permanganat Kalium) dan bahanbahan pendukung lainnya.

c. Langkah Pembuatan Alat Deteksi Deteksi Sederhana Boraks (modifikasi dari metode (Hartati, 2017)

Cara1: Kertas saring

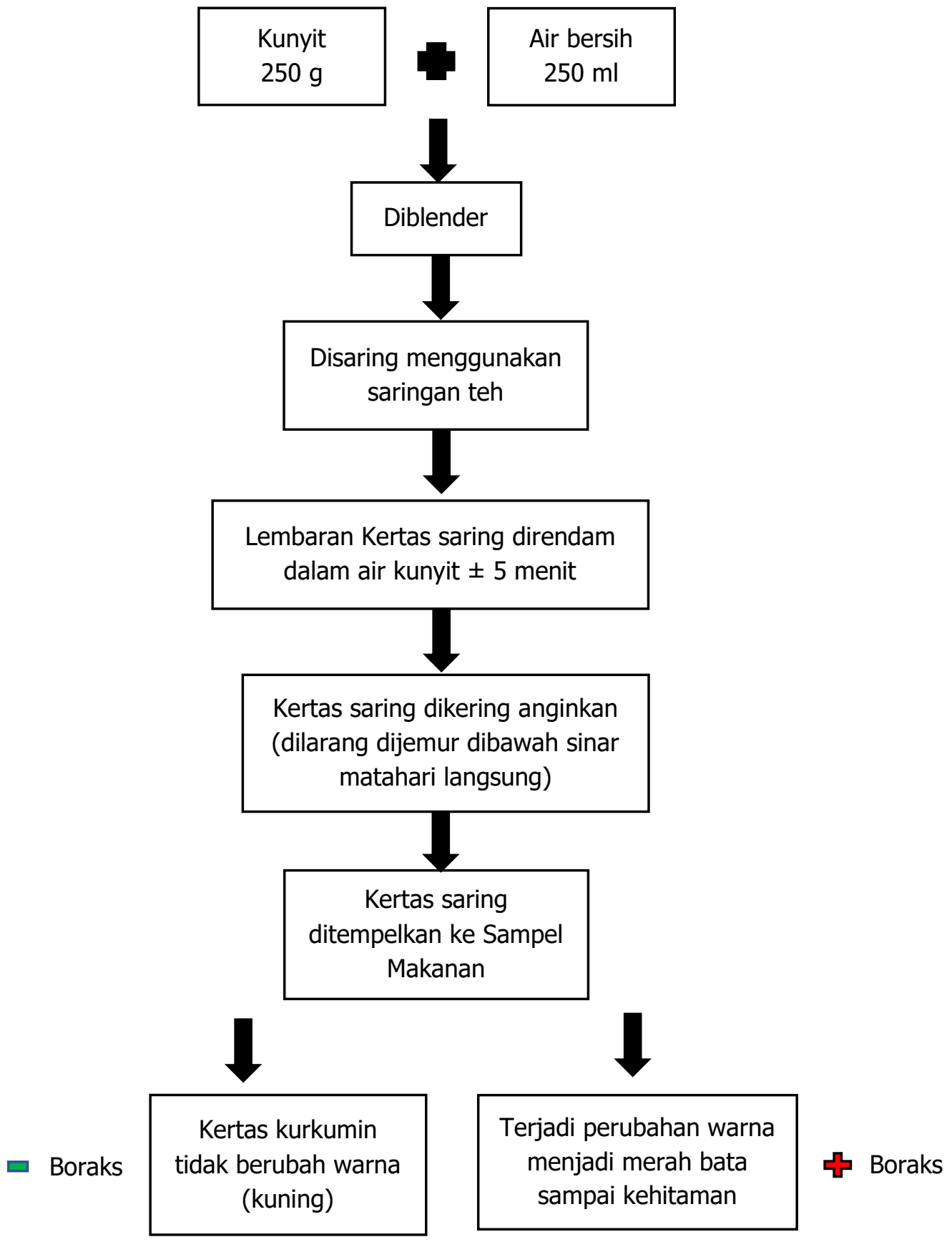

Gambar 1. Skema Pembuatan dan Pengujian Boraks dengan kertas saring 
Cara 2: Tusuk Gigi

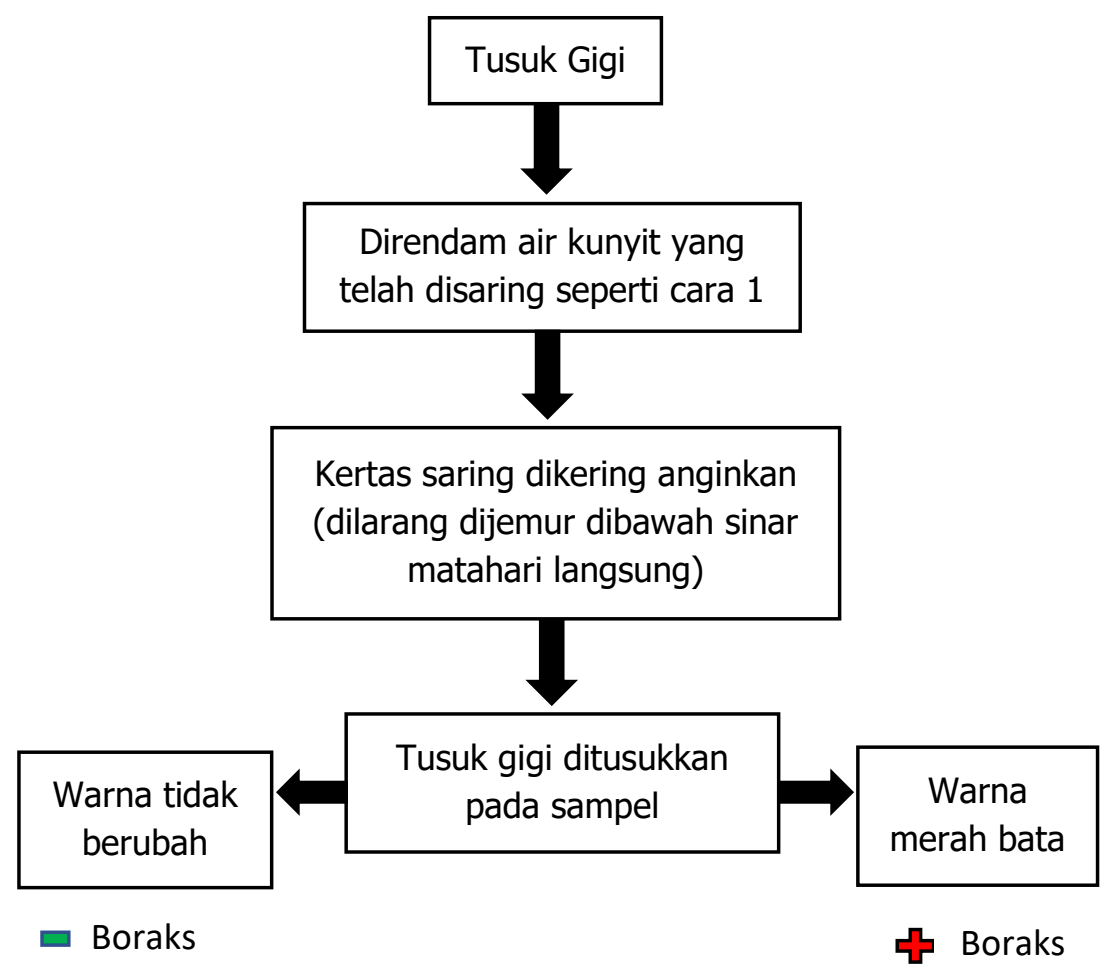

Gambar 2. Skema Pembuatan dan Pengujian Boraks dengan tusuk gigi

d. Langkah Pengujian Formalin Pada Bakso menggunakan Kalium Permanganat $\left(\mathrm{KMnO}_{4}\right)$.

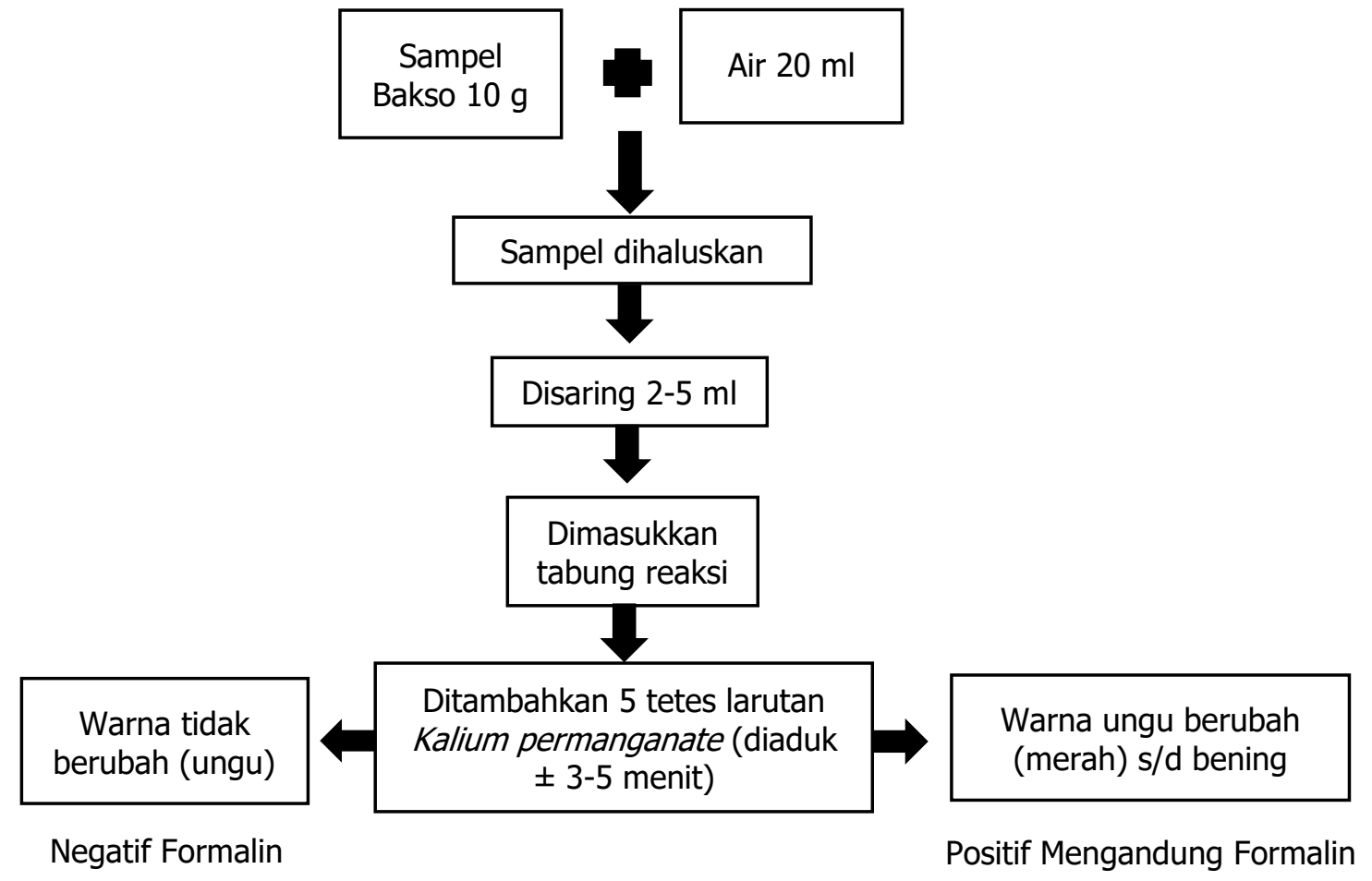

Gambar 3. Skema pengujian formalin dengan kalium permanganat 


\section{Hasil dan Pembahasan}

Permasalahan yang paling mendasar yang dapat diidentifikasi di Desa Lempuan Kecamatan Janapria saat ini adalah pertama, mengenai ketidakpahaman masyarakat mengenai jenis-jenis bahan tambahan pangan dan bahan tambahan pangan yang berbahaya serta bagaimana cara mendeteksinya. Kedua, ketidak pedulian masyarakat dalam memilih makanan dan minuman yang dikonsumsinya. Ketiga, pengetahuan dan kepedulian Guru yang minim mengenai adanya bahan makanan berbahaya di sekitar sekolah yang dikonsumi murid-murid di sekolah. Karena guru merupakan pengendali dan penggerak utama semua kegiatan di sekolah, sehingga dapat memberikan pelajaran dan nasihat kepada peserta didik tentang bahaya mengkonsumsi makanan yang diduga mengandung pengawet berbahan boraks.

Kegiatan proses pendampingan penyuluhan dan pelatihan pembuatan alat deteksi cepat dan sederhana boraks dan formalin (Gambar 4).
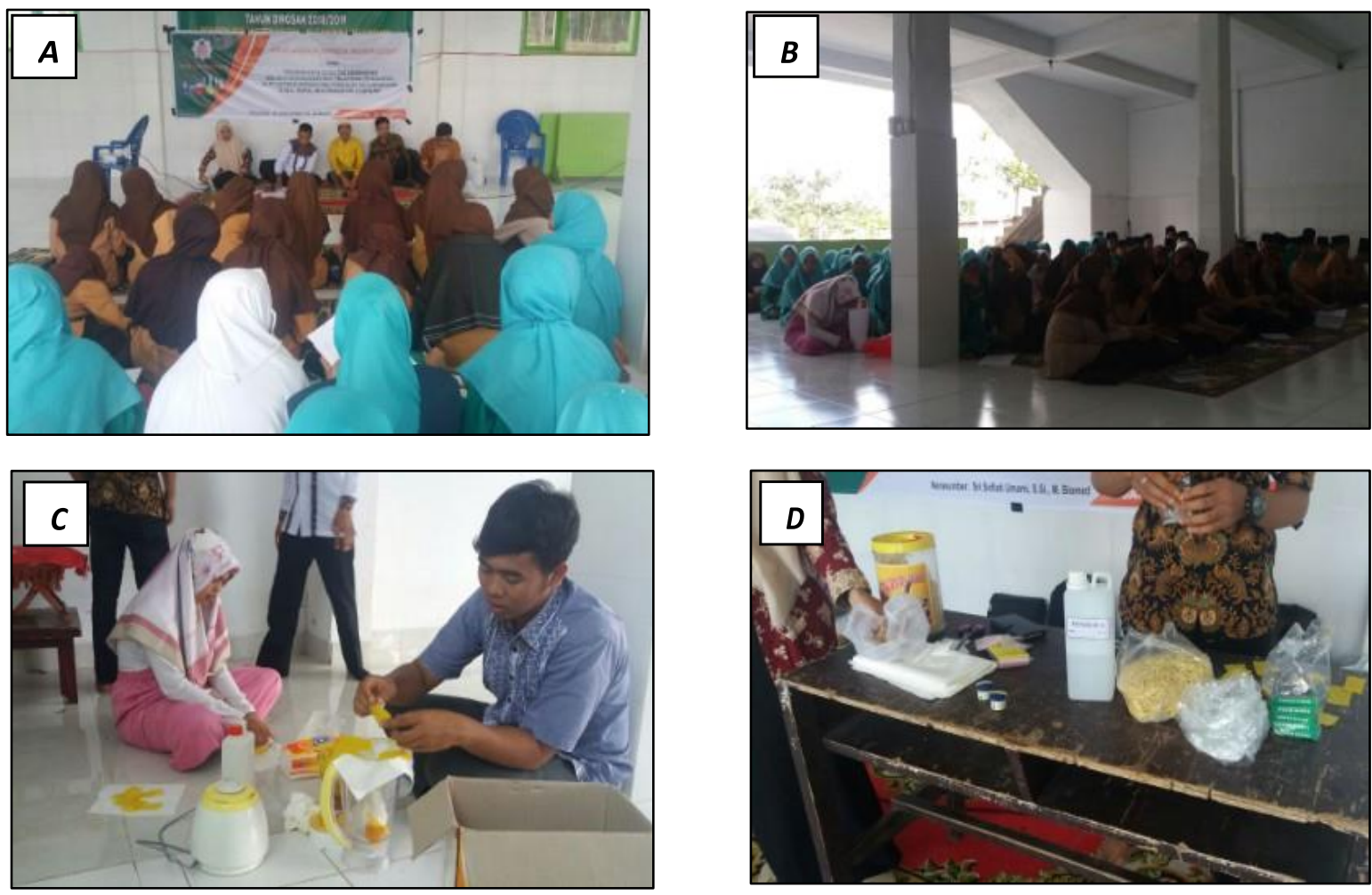

Gambar 4. A. Pelaksanaan kegiatan pengabdian masyarakat; B. Proses sosialisasi bahaya penggunaan bahan tambah pangan boraks dan formalin; C - D Proses pembuatan alat deteksi cepat dan sederhana boraks dan formalin menggunakan kertas saring, tusuk gigi dan kalium permanganat

Berdasarkan hasil pembuatan kertas kurkumin didapatkan \pm 60 potong kertas dengan ukuran $2 \times 4 \mathrm{~cm}$ dan 3 kotak tusuk gigi yang sudah dilapisi senyawa kurkumin. Pengujian menggunakan kertas kurkumin dan kalium permanganate pada semua sampel yang digunakan yaitu mie kuning basah dan kerupuk nasi yang berasal dari daerah sekitar menunjukan hasil positif borax dan positif formalin (sampel cilok). Positif borax ditunjukan dengan perubahan warna kuning menjadi merah kehitaman, sedangkan positif formalin ditunjukan dengan perubahan warna dari hitam kemerahan menjadi lebih bening. Perubahan warna tersebut 
disebabkan karena adanya reaksi kurkumin yang dapat berikatan dengan asam borat yang kemudian akan membentuk komponen rososianin berwarna merah sehingga dapat diamati secara visual (Halim et al., 2012).

Monitoring dan evaluasi dilakukan melalui proses diskusi setelah penyuluhan dan pelatihan dilakukan. Evaluasi hasil ini bertujuan untuk mengetahui respon masyarakat khususnya guru dan siswa madrasah, dan dampak dari kegiatan penyuluhan. Didapatkan hasil bahwa adanya penyuluhan dan pelatihan ini dapat meningkatkan pemahaman dan kesadaran akan bahaya boraks dan formalin, karena pada dasarnya sebelum adanya pelatihan ini masyarakat tidak mengetahui bahaya penggunaan boraks dan formalin bagi kesehatan, hal ini sesuai dengan hasil diskusi langsung dengan guru dan siswa di madrasah tersebut. Selain itu, masyarakat tidak mengetahui bahwa bahan tambah yang digunakan untuk membuat kerupuk nasi dan mie adalah bahan yang mengandung boraks dan formalin karena nama bahan yang beredar di masyarakat bukan boraks akan tetapi disamarkan dengan nama lain. Hal ini sesuai dengan pernyataan Hartati (2017), yang menyebutkan bahwa faktor pengetahuan mempengaruhi perilaku hidup bersih dan sehat pada masyarakat, akan tetapi faktor ekonomi dan Pendidikan tidak berpengaruh nyata. Selanjutnya pada penelitian lain juga disebutkan bahwa adanya pengaruh Pendidikan dan pemahaman terhadap tingkat Kesehatan masyarakat tersebut (Sriyono, 2015). Dengan kata lain, masyarakat akan peduli terhadap Kesehatan jika paham akan jenis-jenis bahan tambah pengan serta bahayanya bagi Kesehatan tubuh. Secara umum banyak faktor yang mempengaruhi tingkat Kesehatan masyarakat yaitu faktor lingkungan, perilaku, keturunan dan pelayanan Kesehatan (Eliana, 2016).

Dengan adanya evaluasi ini diharapkan dapat dijadikan sebagai dasar dalam pengambilan langkah pendampingan yang selanjutnya. Hasil diskusi (tanya-jawab) dengan peserta pengabdian, sosialisasi dan pelatihan pembuatan alat deteksi cepat dan sederhana tersebut memiliki dampak positif dan merubah pola fikir guru dan siswa untuk tidak sembarang menggunakan dan mengkonsumsi bahan tambah pangan berbahaya berupa boraks dan formalin. Guru dan siswa lebih selektif dalam memilih makanan yang dikonsumsi, khususnya makanan dan jajanan yang biasa dijajakan keliling oleh penjual. Dengan adanya kegiatan ini masyarakat lebih mengerti dan peduli terhadap kesehatan masing-masing bahkan keluarganya.

Sosialisasi dan pelatihan ini dimaksudkan untuk membantu memberikan pemahaman kepada guru dan siswa serta masyarakat tentang bahaya penggunaan bahan tambah pangan berupa formalin dan boraks. Selain itu, pelatihan ini dimaksudkan untuk membantu guru dan siswa serta masyarakat mempermudah dalam membedakan bahan pangan atau makanan yang mengandung borakss dan formalin. Adanya kegiatan ini sangat direspon positif oleh guru dan siswa di Madrasah Aliyah (MA) Nurul Mujtahidin NW Lempuan Desa Durian, Kecamatan Janapria Lombok Tengah, guru dan siswa aktif dalam bertanya dan berdiskusi serta aktif terlibat langsung dalam demo pembuatan alat deteksi sederhana dan cepat tersebut. 


\section{Kesimpulan}

Kegiatan pengabdian kepada masyarakat melalui pelatihan pembuatan alat deteksi sederhana boraks dan formalin dapat memberikan skill pada guru, siswa dan perwakilan masyarakat dalam membuat alat deteksi sederhana boraks dan formalin serta mampu mengaplikasikannya pada makanan dan minuman yang biasa dikonsumsi masyarakat tersebut.

\section{Ucapan Terima Kasih}

Pengabdian ini dapat terlaksana atas Hibah Pengadian Masyarakat dari Lembaga Penelitian dan Pengabdian Masyarakat (LP2M) Universitas Islam Negeri Mataram. Penulis juga menyampaikan terimakasih atas kerjasama yang baik mitra pengabdian yaitu Madrasah Aliyah Nurul Mujtahidin NW Lempuan Desa Durian, Kecamatan Janapria Lombok Tengah.

\section{Referensi}

Asif Ahmed, M., Al-Khalifa, A. S., Al-Nouri, D. M., \& El-din, M. F. S. (2020). Dietary intake of artificial food color additives containing food products by school-going children. Saudi Journal of Biological Sciences, (xxxx). https://doi.org/10.1016/j.sjbs.2020.08.025

Atiqullah, S. M., Palit, A., Reja, M. I., Akhtar, J., Fatema, S., \& Absar, R. (2019). Detection of harmful food additives using highly sensitive photonic crystal fiber. Sensing and Bio-Sensing Research, 23(October 2018), 100275. https://doi.org/10.1016/j.sbsr.2019.100275

Badan Pengawas Obat dan Makanan Republik Indonesia. (2011). Pedoman Cara Ritel Pangan yang Baik.

Boutillier, S., Fourmentin, S., \& Laperche, B. (2020). Food additives and the future of health: An analysis of the ongoing controversy on titanium dioxide. Futures, 122 (June), 102598. https://doi.org/10.1016/j.futures.2020.102598

BPOM Mataram. (2017). Laporan Kinerja Tahun 2017 BBPOM di Mataram (Vol. 53). Mataram: BPOM Mataram.

Cahyadi, Wisnu., (2008). Analisis dan Aspek Kesehatan Bahan Tambahan Pangan. Jakarta: PT. Bumi Aksara,

Eliana, S. S. (2016). Kesehatan Masyarakat. Jakarta: Kementerian Kesehatan Republik Indonesia.

Femi-Oloye, O. P., Owoloye, A., Olatunji-Ojo, A. M., Abiodun, A. C., Adewumi, B., Ibitoye, B. O., ... Akinwumi, F. O. (2020). Effects of commonly used food additives on haematological parameters of Wistar rats. Heliyon, 6(10), e05221. https://doi.org/10.1016/j.heliyon.2020.e05221

Halim, A. A., Fattah, A., Bakar, A., Ahmad, M., Megat, K., Zakaria, H., ... Pahang, M. (2012). Boron Removal from Aqueous Solutions Using Curcumin-Aided Electrocoagulation Environmental Health Programme, Faculty of Allied Health Sciences ,. 11(5), 583-588.

Hartati, F. K. (2017). Analisis Borakss Dengan Cepat, Mudah Dan Murah. Jurnal Teknologi Proses Dan Inovasi Industri, 2(1), 33-37. https://doi.org/10.36048/jtpii.v2i1.2827

Kementerian Kesehatan Republik Indonesia. (2012). Peraturan Menteri Kesehatan Republik Indonesia Nomor 033 Tahun 2012 Tentang Bahan Tambahan Pangan (Vol. 033). Jakarta: Kementerian Kesehatan.

Lemoine, A., Pauliat-Desbordes, S., Challier, P., \& Tounian, P. (2020). Adverse reactions to food additives in children: A retrospective study and a prospective survey. Archives de Pediatrie, 277), 368-371. https://doi.org/10.1016/j.arcped.2020.07.005

Oktaviani I \& Yandra A., (2017). Preventif Approch: Bahaya Boraks dan Cara Mengidentifikasi Makanan yang Mengandung Boraks. Dinamisia Jurnal pengabdian Masyarakat. 1 (1).

Pradono, J., \& Sulistyowati, N. (2014). Hubungan Antara Tingkat Pendidikan, Pengetahuan Tentang Kesehatan Lingkungan, Perilaku Hidup Sehat Dengan Status Kesehatan (Studi Korelasi Pada Penduduk Umur 10-24 Tahun di Jakarta Pusat). Buletin Penelitian Sistem Kesehatan, 17(1), 8995. Retrieved from https://www.neliti.com/publications/20885/correlation-between-education- 
Transformasi: Jurnal Pengabdian Masyarakat, Vol. 16, No. 2, Desember 2020: 194-202

level-knowledge-of-environmental-health-healthy-be

Sriyono. (2015). Pengaruh Tingkat Pendidikan Dan Pemahaman Masyarakat Tentang Ikan Berformalin Terhadap Kesehatan Masyarakat. Jurnal Faktor Exacta, 8(1), 79-91.

Swi See, A., Bakar Salleh, A., Abu Bakar, F., Azah Yusof, N., Sahib Abdulamir, A., \& Yook Heng, L. (2010). Risk and Health Effect of Boric Acid. American Journal of Applied Sciences, 75), 620627. Retrieved from http://thescipub.com/PDF/ajassp.2010.620.627.pdf

Ziska, L., et al,. 2016., FoodSafety, Nutrition, and Distribution. The Impacts of Climate Change on Human Health in the United States: A Scientific Assessment. U.S. Global Change Research Program. Washington: DC, 189-216. 